Kritische bibliografie

\title{
FILOSOFIE EN TERREUR. HABERMAS EN DERRIDA OVER DE BETEKENIS VAN 9/11
}

\author{
Antoon Braeckman
}

Jürgen Habermas \& Jacques Derrida, Filosofie in een tijd van terreur. Gesprekken met Giovanna Borradori (Filosofie in dialoog), Kampen Antwerpen, Klement - Pelckmans, 2004, 238 p. - ISBN 9028934812

Aanleiding voor dit boek, zo vertelt ons Giovanna Borradori in het voorwoord, zijn behalve de gebeurtenissen van 11 september 2001, het merkwaardig toeval dat zowel Jürgen Habermas als Jacques Derrida in de herfst van datzelfde jaar voor langere tijd in New York verbleven. Die coïncidentie bracht haar op het idee om beide coryfeeën van het hedendaagse denken te polsen naar hún inschatting van de betekenis van $9 / 11$.

Het interview met Derrida vond plaats op 22 oktober 2001. Derrida was toen reeds drie weken in New York, wat impliceert dat hij in de stad moet zijn aangekomen toen Ground Zero nog aan het nasmeulen was. Het gesprek met Habermas volgde dan in december van datzelfde jaar. In weerwil van wat de reekstitel van deze uitgave suggereert, gaat het hier dus niet echt om een dialoog tussen Habermas en Derrida, al maakt interviewster Borradori zich sterk dat beide heren voor het eerst op een zelfde reeks vragen reageren waardoor het dialogale gehalte van het dubbelinterview aanzienlijk stijgt. Maar daartegenover staat dan weer dat het voor de lezer niet duidelijk is in hoeverre de tekst die hier aangeboden wordt correspondeert met het feitelijke interview. Zo valt het op dat het interview met Habermas hooguit twintig bladzijden beslaat, terwijl dat met Derrida een volle zestig bladzijden loopt. Derrida's tekst is bovendien voorzien van een uitgebreid voetnotenapparaat van de hand van de meester zelf, terwijl alle voetnoten bij het Habermas-interview van de hand zijn van Borradori. Derrida heeft de interviewtekst dus zeker en vast gereviseerd, maar het blijft onduidelijk wanneer dit precies is gebeurd en hoe ingrijpend. In elk geval getuigt dit interview bij wijlen van zo'n 'voorzienigheid' inzake de geopolitieke gevolgen van $9 / 11$, dat men moet aannemen dat die passages in het 'interview' lang na 22 oktober 2001 - en dus met méér 'kennis van zaken' geschreven zijn. Mogelijk verklaart dit ook het merkwaardige feit dat het interview met Habermas, dat pas in december van 2001 werd afgenomen, in het boek afgedrukt 
staat vóór het gesprek met Derrida. - Hier ligt dus nog een aardige kluif voor eventueel latere tekstkritische edities van beide interviews.

Het boek bevat evenwel meer dan alleen maar de 'naakte' interviews met Habermas en Derrida. Borradori heeft van de gelegenheid gebruik gemaakt om - met wisselend succes - beide interviews te voorzien van een uitgebreid commentaar, en het geheel aan de hand van een inleidend essay te plaatsen tegen een ruimere historisch-filosofische achtergrond. Vooral het inleidende essay en het commentaar bij het interview met Derrida doen hier uitstekend dienst. Het inleidende essay duidt de centrale thema's uit beide interviews - de ambivalenties van de moderniteit, de idealen van de Verlichting, de vaagheid van de term 'terrorisme' - vanuit de bredere filosofische posities van Habermas en Derrida, terwijl het commentaar een heldere rode draad weet te weven in de complexe textuur van het interview met Derrida. Daartegenover zijn Borradori's toelichtingen bij de antwoorden van Habermas bij wijlen redundant - vaak herhaalt ze gewoon wat Habermas eerder al (beter) formuleerde - en soms wat geforceerd. Het geheel wekt op die manier de indruk dat de interviewster méér vertrouwd is - en ook meer sympathiseert - met het denken van Derrida, dan met de posities van Habermas.

Toch ligt één van de opmerkelijkste charmes van het boek in de vaststelling dat Habermas en Derrida vanuit hun toch grondig verschillende filosofische posities tot gelijkluidende evaluaties komen van de gebeurtenissen van 11 september en vooral van wat daarin uiteindelijk op het spel staat. Beiden zijn ze ervan overtuigd dat een dergelijke terreurdaad haar oorsprong vindt in een ideologie die de moderniteit en de secularisatie, en met name de Verlichting afwijst. Precies daarom geloven ze mét Borradori ook dat de filosofie - die mee de basis heeft gelegd van de Verlichting - een unieke bijdrage kan en moet leveren in het debat omtrent oorzaken en betekenis van het huidige internationale terrorisme. Daarbij verwerpt Habermas dit terrorisme omdat het, in tegenstelling tot de zogenaamde terreur van de 'klassieke' bevrijdingsbewegingen - denken we maar aan het Palestijnse verzet of aan de opstandelingen in Nepal - geen politieke of territoriale doelstellingen meer heeft. De Al-Qaida-terrorist heeft hooguit fundamentalistische motieven, maar verder geen programma dat uitgaat boven het zaaien van verwoesting en onzekerheid. - Een inschatting die bij Derrida naklinkt in de gedachte dat dit terrorisme niet gericht is op een toekomst en dus 'een terrorisme zonder toekomst is' (p. 142). - Allicht gaat het om een afweerreactie tegen de angst voor een gewelddadige ontworteling van de traditionele levensvormen, aldus nog Habermas. De westerse wereld fungeert daarbij als zondebok voor de hoogst reële verlieservaringen waaronder deze uit haar culturele tradities losgerukte bevolking gebukt gaat ten gevolge van de zich in ijltempo voltrekkende moderniseringsprocessen. - Derrida van zijn kant heeft dan weer oog voor de gebrekkige eenduidigheid van termen als 'terrorisme' en 
'internationaal terrorisme', maar ook van uitdrukkingen zoals 'oorlog tegen het terrorisme'. Maar ongeacht die verschillende insteek, zien beiden in de gebeurtenissen in en om $9 / 11$ de overgang van de klassieke internationale rechtsorde, die berust op het negentiende-eeuwse model van de natiestaat, naar een nieuwe kosmopolitische orde waarin multilaterale instellingen en continentale bondgenootschappen de voornaamste politieke actoren zullen worden. In dat verband wijzen Habermas en Derrida erop dat het autoriseren van deze nieuwe internationale instellingen een kritische herijking vooronderstelt van de (klassieke) betekenis van de soevereiniteit. Derrida lijkt hier in eerste instantie verder te willen gaan dan Habermas: "Ik denk dus dat we verder moeten kijken dan het oude Grieks-christelijke kosmopolitische ideaal (de stoïci, de apostel Paulus, Kant) en ons moeten richten op de komst van een universeel verbond van solidariteit dat zich uitstrekt voorbij de grenzen van de internationaliteit van natiestaten en daarmee voorbij de grenzen van het burgerschap" (p. 155). Waarna hij op zijn stappen terugkomt en de ambivalentie van de natiestaat voluit erkent: "We worden altijd teruggevoerd tot dezelfde aporieën: hoe te beslissen tussen, enerzijds, de positieve en heilzame rol die de 'staats'vorm (de soevereiniteit van de natiestaat) en daarmee het democratisch burgerschap vervult bij het bieden van bescherming tegen bepaalde vormen van internationaal geweld (de markt, de concentratie van het wereldkapitaal, evenals het 'terroristische' geweld en de proliferatie van wapens) en, anderzijds, de negatieve of beperkende effecten van een staat waarvan de soevereiniteit een theologische erfenis blijft, een staat die zijn grenzen sluit voor niet-burgers, die geweld monopoliseert, zijn grenzen controleert, niet-burgers buitensluit of onderdrukt enzovoort? Wederom: de staat is zowel zelfbeschermend als zelfdestructief, tegelijkertijd remedie en vergif. Het pharmakon is een andere naam, een oude naam, voor deze auto-immune logica" (p. 155).

Maar evident zijn er tussen beide auteurs en hun kijk op de betekenis van 11 september ook belangwekkende verschillen. Die komen voornamelijk in het vizier wanneer de achterliggende interpretatiekaders aan de oppervlakte komen van waaruit beiden hun diagnose van 11 september formuleren. Zo duidt Habermas het recente internationale terrorisme primair als een communicatiestoornis, dit is als het mislukken van communicatieve handelingsprocessen tussen de betrokken cultuur-gemeenschappen. Perfect in lijn met zijn bekende thesis van de 'kolonisering van de leefwereld' schrijft hij die mislukking toe aan de al te snelle en eenzijdig economisch georiënteerde moderniseringsprocessen waaraan de veelal nog erg traditioneel gestructureerde cultuurgemeenschappen onderworpen worden, en de defensieve reactie die dit alles bij die gemeenschappen heeft uitgelokt. Als oplossing hoopt Habermas op een herstelde communicatie, mede mogelijk gemaakt, zoals boven aangegeven, door de uitbouw van een internationale rechtsorde en van versterkte 
internationale instellingen. Habermas houdt dus ook in deze vast aan de idee van een 'modern project' dat te voltooien valt, en dat in en door die voltooiing ook bevrijd wordt van zijn pathologieën - zelfs al nemen die in de huidige constellatie de gedaante aan van een internationaal, niets of niemand ontziend terrorisme. Derrida's optiek in deze is behoorlijk verschillend. Ook hij begrijpt het huidige terrorisme als een 'moderne pathologie', zij het dat het om een ziektebeeld gaat waarvan de moderniteit nadrukkelijk niet genezen kan. Terwijl voor Habermas de rede, begrepen als de mogelijkheid van transparante en nietmanipulatieve communicatie, de kwalen van de modernisering met inbegrip van fundamentalisme en terrorisme kan genezen, kunnen deze destructieve spanningen volgens Derrida weliswaar opgespoord en benoemd, maar nooit volledig beheerst of overwonnen worden. Daarom begrijpt hij het terrorisme, zoals het zich vandaag aandient, liever in termen van 'een auto-immuunstoornis' die het bestaan bedreigt van de participerende democratie, het rechtssysteem dat erop geënt is en de mogelijkheid van een scherpe scheiding tussen de godsdienstige en wereldlijke dimensies van de modeme samenleving. Kenmerkend voor auto-immuunstoornissen is namelijk "het vreemde gedrag waarbij een levend wezen op quasi-suïcidale wijze, 'zelf' bezig is zijn eigen bescherming te vernietigen, zichzelf immuniseert tegen zijn 'eigen' immuniteit" (p. 119). En dus bijzonder kwetsbaar wordt! Op het niveau van onze westerse samenleving doet zich iets gelijkaardigs voor. Onze samenleving heeft diverse afweersystemen ontwikkeld om zich tegen allerlei aanvallen van buitenaf te verdedigen. Maar in gebeurtenissen zoals $9 / 11$ blijken die systemen zich plots tegen die samenleving zelf te keren. Op dat ogenblik wordt de samenleving bedreigd door systemen die precies in het leven zijn geroepen om externe dreigingen het hoofd te bieden. In het geval van 11 september laat die autoimmuunstoornis zich gemakkelijk documenteren onder verwijzing naar het feit dat de kapers opgeleid werden in het land dat ze vervolgens - mét de techniek van dat land - hebben aangevallen of onder verwijzing naar Osama Bin Laden die tijdens de oorlog in Afghanistan door de V.S. werd bewapend om het verzet tegen de Sovjet-Unie te ondersteunen, en die na verloop van tijd die know-how en middelen opnieuw inzet tegen de V.S. zelf. Maar ook op een meer algemeen niveau is er volgens Derrida sprake van een auto-immuunstoornis. Kennelijk brengen de V.S. - en bij uitbreiding de westerse samenleving en haar moderne cultuur - steeds weer de monstruositeiten voort die ze pretenderen te overwinnen of pretenderen reeds overwonnen te hebben. Elke verdringing, zo profeteert Derrida, regenereert echter wat ze probeert onschadelijk te maken. Zo zal elke war on terrorism op korte of lange termijn de oorzaken van het kwaad dat ze wil uitroeien nieuw leven inblazen (p. 126). Een gedachte die Derrida onmiddellijk bij de reeds gesignaleerde 'vaagheid' van de notie 'terrorisme' of 'internationaal terrorisme' brengt: waar eindigt immers de oorlog tegen het terrorisme en wordt 
hij zelf een vorm van terrorisme? De scheidingslijnen tussen beide, zo stelt Derrida vast, dreigen vandaag volkomen te vervagen.

Onvermijdelijk mondt een gesprek over de dreiging van het internationale terrorisme en de achterliggende spanningen tussen culturen en cultuurgemeenschappen uit bij de vraag naar tolerantie. Maar ook hier gaan de wegen van Habermas en Derrida uiteen. Mogelijk situeert zich in die kwestie wel het belangrijkste verschil tussen beide denkers. Derrida is namelijk van mening dat tolerantie een vorm van liefdadigheid en dus een vorm van paternalisme is. Uit 'goodwill' is men bereidt de ander te accepteren, althans tot op zekere hoogte: onder welbepaalde voorwaarden en restricties. Bijvoorbeeld onder voorwaarde dat men zich gedraagt conform de plaatselijke normen en wetten, en dus in elk geval op voorwaarde dat men zich bewust blijft dát men getolereerd wordt. Tegenover die tolerantie stelt Derrida 'gastvrijheid': de echte, onvoorwaardelijke gastvrijheid; niet de voorwaardelijke, omzichtige, angstvallige gastvrijheid - de benedengrens van de gastvrijheid, die de tolerantie is. Daarmee opent Derrida een perspectief op een 'onwereldse' dimensie, een onbereikbaar ideaal van rechtvaardigheid, dat als regulatieve idee richtinggevend moet zijn én blijven voor de wijze waarop wij de ander feitelijk bejegenen. - Voor Habermas, daarentegen, voldoet de tolerantie wel, althans wanneer ze gepraktiseerd wordt binnen de context van een democratische gemeenschap. In een democratie, aldus nog Habermas, kan de tolerantie zich immers ontvouwen op een niet-caritatieve, op een niet-paternalistische wijze, omdat "op grond van de gelijkwaardigheid van de burgers en hun wederzijdse respect voor elkaar, niemand het privilege bezit om de grenzen van de tolerantie slechts vanuit het perspectief van de eigen waardeoordelen vast te stellen" (p. 97).

Daarmee heb ik slechts enkele van de thema's aangehaald die tijdens beide interviews beknopt of uitvoeriger zijn gethematiseerd. Maar intussen mag het duidelijk zijn dat dit dubbelinterview - én het bijhorend commentaar, dat dient er uitdrukkelijk aan toegevoegd - op een boeiende en bijzonder actuele wijze toegang biedt tot het denken van twee van de belangrijkste hedendaagse filosofen. Bovendien - en dat is ongetwijfeld de verdienste van deze uitgave laat het boek glashelder zien hoe abstracte en vaak moeilijk toegankelijke theoretische posities op consistente wijze vertaald kunnen worden naar concrete politieke en politiekfilosofische stellingnames, of nog: hoe dergelijke concrete stellingnames als het ware geïmpliceerd liggen in de abstracte theoretische, speculaties van hun auteurs. De lectuur van het boek verschaft de lezer daarom het plezier getuige te zijn van een 'levende', op maat van de eigen tijd gesneden filosofie. - Bovendien, en ook dat dient nadrukkelijk vermeld, is de vertaling vlekkeloos en de globale editie, ook inzake noten en referenties, ronduit uitstekend. 